\title{
The use of satellite images in the morphological analysis of the Siret riverbed between Cosmești and Galați
}

\author{
Diana Alexandra Marola \\ Doctoral School "Simion Mehedinți" \\ Faculty of Geography, University of Bucharest \\ Bucharest, Romania \\ dianaalexandramarola@gmail.com
}

\begin{abstract}
The objective of this work consists in identifying the changes produced in the Siret River, using satellite images.

The study area is represented by a sector of the Siret Plain, heavily influenced by the dynamics of the Siret River reflected in morphology, landscape features, land use, and anthropogenic elements.
\end{abstract}

The working methodology consisted in combining the techniques of remote sensing and GIS in the processing of satellite images Landsat 7 ETM and OLI L8 from 2003 and 2016, aiming the classification of this images according to a few categories of land use in order to observe the dynamics of their distribution in space and time. The main categories of use of land on which we have focused the analysis are located in close proximity to bodies of water. To process images in different spectral bands combinations and vector analysis, we used ArcGis application and related modules.

The results of the analysis of satellite images based on processing, are represented by small differences identified between the categories of land use in the proximityy of the Siret River within the area studied, between the years of 2003-2016.

Keywords_-GIS; satellite images; land use

\section{INTRODUCTION}

This project aims to use satellite imagery for obtaining advanced information related to changes of the relief, geographical elements, and changes of function of the landscape.

The area of study is a low plain area, influenced, in particular, by the dynamics of its main element, the Siret River Valley. The Siret River Dynamics has a major influence on the characteristics of landscape and anthropogenic elements.

\author{
Laura Comănescu \\ Department of Geomorphology, Pedology - Geomatics \\ Faculty of Geography, University of Bucharest \\ Bucharest, Romania
}

\section{AREA OF STUDY}

The studied area is located between Cosmești (North) and Galați Municipality (South) and is located at the contact of the four counties, namely: Vrancea County (Northwest), Galați County (North and East), Brăila (South) and Buzău (Southwest). The position of the area studied is apparent in the following figure:

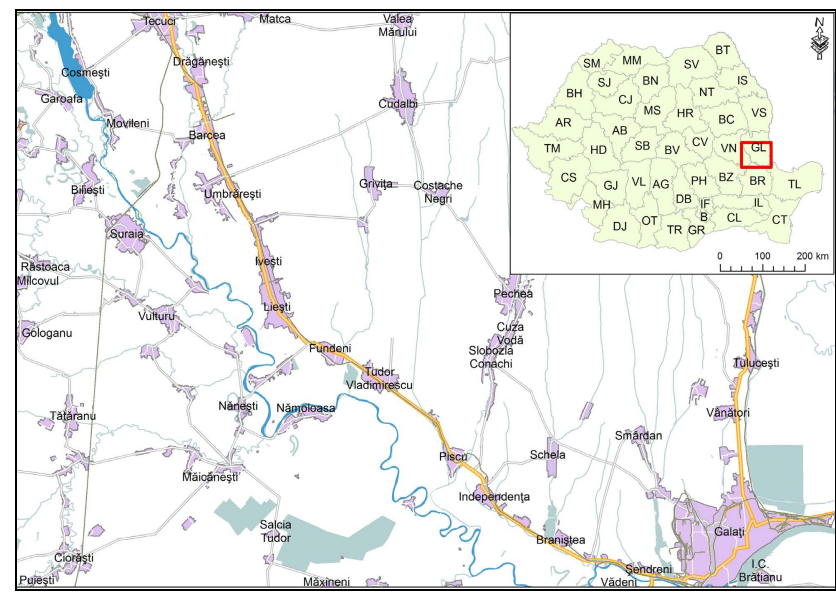

Fig. 1. The location of the studied area

\section{DATA AND METHODOLOGY}

The methodology used for the analysis was based on the identification of several categories of land use on both satellite images, in order to observe the dynamics of their distributions in space and time. The processing software used to analyze the images and to extract the relevant information, were SNAP and ArcGis.

There were used only those combinations of bands which were considered more relevant in accentuating the relevant information for this study. Also, it was used a certain type of pixel classification to represent the distribution of the categories of land use establish. 
Basically, there were obtained certain classifications of pixels, which represent operations based on mathematical algorithms, obtained in digital environment, in order to group pixels with different spectral signature from an image or to group those pixels for which it is known their signification in the field.

Within this phase, it could have been used either an unsupervised classification or a supervised classification. An unsupervised classification means that the value of the pixel it is not known, and involves a differentiation of pixels depending on the spectral signature. For this study, it was chosen the supervised classification which is based on the fact that the analyst knows the significance on the field of the spectral signature corresponding to the pixels in the image.

Before the classification itself, there were chosen a series of groups of pixels with known meaning, as homogeneous in terms of spectral signatures depending on which all pixels in the image will be grouped into categories. This groups shall be called test areas or regions of interest. The same areas of interest have been selected in both images processed, in order to have a correct development of the dynamics of their distribution.

The regions of interest for this study were:

- Water bodies;

- Silt;

- Forests;

- Areas of transition with shrubs;

- Pasture;

- Vineyards;

- Human settlements;

- Agricultural land.

The next step was the actual realization of the classification on the imagery chosen, stage which involves running some mathematical algorithms centered on the test areas for comparison and analysis of the pixels in order to group them in different classes. There are several types of classifications supervised, but the method chosen was a Maximum Likelihood Classification that uses the principle that each cell chosen from each class is distributed normally. So, for each satellite image, it was used a certain combination of bands, the areas of interest were chosen and the supervised classification of the image has been carried out using the specified method.

Subsequently, it was extracted a range of statistical information from previously completed transactions, representing practically the main purpose of this study.

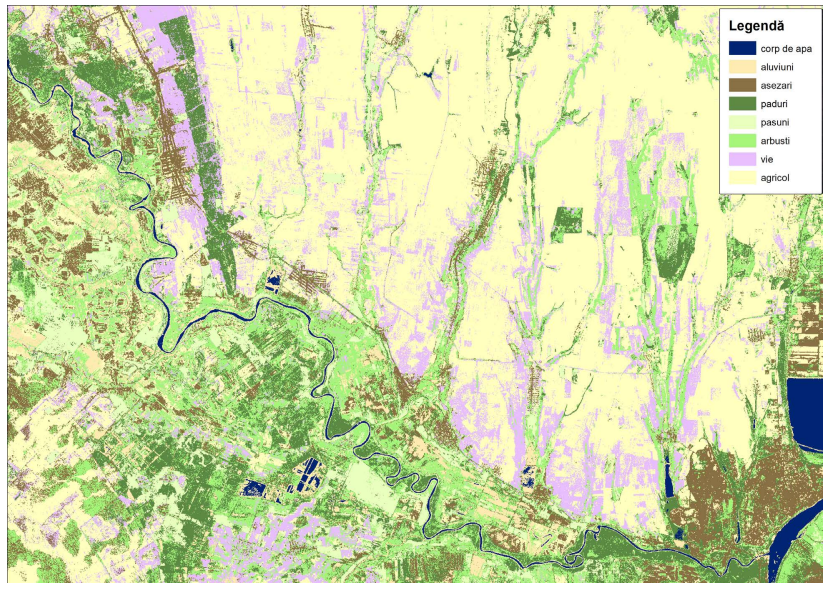

Fig. 2. Maximum Likelihood Classification

\section{RESULTS}

The results of the analysis of satellite images based on processing, are represented by small differences identified between the categories of land use in the proximity of the Siret River within the area studied, between the years of 2003-2016.

\section{REFERENCES}

[1] B. Mihai, Aplicaţii ale aerofotogramelor la scară mare în cercetarea impactului antropic în spaţiul montan, A XXVII-a Sesiunde de comunicări ştiinţifice cu participare internaţională, Ed. Academiei Tehnice Militare, Bucureşti, 1997. (in Romanian)

[2] Agenţia Europeană de Mediu, Corine Land Cover 2006 seamless vector data - version 13 (02/2010), [Available online] | URL: http://www.eea.europa.eu/data-and-

maps/data\#c12=corine + land + cover+version +13 , data accesării: 19.04.2011, ora 12.52 .

[3] Earth Resources Observations and Sience Center (EROS), USGS Glabal Visualisation Viewer, [Available online] |URL: http:/glovis.usgs.gov/AboutBrowse.shtml, data accesării: 7.11.2010 ora 13.23, 21.05.2011 ora 12.30.

[4] V. Crăciunescu, România: seturi de date vectoriale generale, [Available online] | URL: http://earth.unibuc.ro/download/romaniaseturi-vectoriale, data accesării: 19.04.2011, ora 13.55.

[5] Global Land Cover Facility, Earth Sienece Data Interface, [Available online] | URL: http://glcfapp.glcf.umd.edu:8080/esdi/index.jsp, data accesării: 15.04.2010, ora 15.25 , 23.05.2011, ora 22.36 - imagini satelitare Landsat ETM+.

[6] Shuttle Radar Topography - The Mision to Map the World, Imagini SRTM [Available online] | URL: http://dds.cr.usgs.gov/srtm/, data accesărtii: 13.03.2009, 24.04.2011.

[7] ***, Understending GIS. The Arc/INFO Method, ESRI, Regland, USA, 1996. 